J. Amer. Soc. Hort. Sci. 117(4):563-567. 1992.

\title{
Nitrogen Nutrition of Containerized Eastern Redcedar. I. Growth, Mineral Nutrient Concentrations, and Carbohydrate Status
}

\author{
Paul H. Henry ${ }^{1}$, Frank A. B1azich ${ }^{2}$, and L. Eric Hinesley ${ }^{2}$ \\ Department of Horticultural Science, North Carolina State University, Raleigh, NC 27695-7609
}

Robert D. Wright ${ }^{2}$
Department of Horticulture, Virginia Polytechnic Institute and State University, Blacksburg,
VA 24061

Additional index words. Juniperus virginiana, fertilization, foliar analysis, conifer, Christmas trees

\begin{abstract}
Containerized seedlings of eastern redcedar (Juniperus virginiana L.) were fertilized weekly for 175 days with a solution containing $50 \mathrm{ppm} P, 150 \mathrm{ppm} \mathrm{K}$, and either $0,5,10,20,40,80,160,320$, or $640 \mathrm{ppm} \mathrm{N}$. Plant height, stem diameter, and shoot and root dry weights increased asymptotically with applied $\mathrm{N} ; 640 \mathrm{ppm} N$ diminished response. Growth after 175 (height, stem diameter) and 180 (shoot and root dry weights) days was optimal (90\% of maximum) at $N$ concentrations of $115,155,230$, and $105 \mathrm{ppm}$, respectively, $1.5 \%$ foliar $N$ optimized height growth. Foliar concentrations of $\mathrm{N}, \mathrm{P}$, and $\mathrm{K}$ increased in treated plants over the duration of the experiment, while $\mathrm{Ca}$, $\mathrm{Mg}$, and Mn decreased or remained constant. Starch concentration of fertilized plants decreased sharply after initiation of the experiment, but controls showed little change during the first 120 days. Sucrose concentration remained constant over the summer but increased sharply in late fall. At 180 days, foliar concentrations of starch, sucrose, hexose, $\mathbf{N}$, $\mathrm{P}, \mathrm{K}$, and B increased asymptotically with applied N; concentrations of Ca, Mg, and Mn decreased.
\end{abstract}

Eastern redcedar is the most widely distributed conifer in the eastern United States (Johnsen and Alexander, 1974). The species, harvested throughout the Southeastern United States as a Christmas tree, is gaining popularity as an ornamental. The aromatic red heartwood of redcedar is valuable for furniture, and rot-resistant qualities make it useful for fenceposts and outdoor construction, Until recently, commercial demand for trees of sawtimber size has been met by cutting native stands. Such trees, however, are becoming less common, and there is interest in establishing cultivated plantations.

Nitrogen is the element that elicits the most growth when applied to conifers (Landis et al., 1989). Shoot growth is asymptotic with increasing substrate N (Mengle and Kirkby, 1982), and weekly applications of 100 to $150 \mathrm{ppm}$ are adequate for most conifers in containerized culture (Landis et al., 1989). Little is known about the nutritional requirements of eastern redcedar, although growth in the field increases with $\mathrm{P}$ supply up to $\approx 22$ to $34 \mathrm{~kg}$ available P/ha (Fletcher and Ochrymowych, 1955). We are unaware of experiments concerning $\mathrm{N}$ nutrition of this species. Therefore, the objective of this study was to determine the influence of $\mathrm{N}$ application rate on growth, mineral nutrient status, and carbohydrate concentrations of containerized eastern redcedar.

\section{Materials and Methods}

Plant material and growing conditions. Uniform 2-year-old seedlings of eastern redcedar were lifted in mid-Apr. 1989 from

\footnotetext{
Received for publication 12 Sept. 1991. Accepted for publication 18 Mar. 1992 This research was funded in part by the North Carolina Agricultural Research Service (NCARS), Raleigh, NC 27695-7643. Based on a PhD thesis by P.H.H. Assistance of D.M. Pharr and the North Carolina Forest Service is gratefully appreciated. Use of trade names in this publication does not imply endorsement by the NCARS of products named nor criticism of similar ones not mentioned. The cost of publishing this paper was defrayed in part by the payment of page charges. Under postal regulations, this paper therefore must be hereby marked advertisement solely to indicate this fact.

Graduate Research Assistant.

${ }^{2}$ Professor.
}

the Claridge State Forest Nursery, Goldsboro, N.C. Seedlings were heeled into moist soil, stored in darkness at 4C for 2 weeks, and potted in 19-liter plastic pots using a medium of 5 milled pine bark : 1 sand $(\mathrm{v} / \mathrm{v})$ amended with 3.0 and $1.5 \mathrm{~kg}$ dolomitic lime and gypsum $/ \mathrm{m}^{3}$, respectively. After potting, lateral shoot growth was removed from the proximal $10 \mathrm{~cm}$ of stems. Stems were marked $2.5 \mathrm{~cm}$ beneath the lowermost remaining foliage, and both height and stem diameter measurements originated at this point.

Each container was topdressed with $10 \mathrm{~g}$ of a micronutrient supplement containing S (12\%), B (0.1\%), Cu (0.5\%), Fe (12\%), Mn (2.5\%), Mo (0.05\%), and Zn (1.0\%) (Micromax, Sierra Chemical, Milpitas, Calif.). An additional application of $30 \mathrm{~g}$ gypsum was topdressed in early August. Pots were placed outside in full sunlight at University Research Unit 4, Raleigh, and irrigated twice daily with overhead sprinklers.

Fertilizer treatments and design of experiment. Fertilizer treatments, initiated 2 weeks after potting, consisted of a solution containing $50 \mathrm{ppm} \mathrm{P}$ (supplied by $\mathrm{H}_{3} \mathrm{PO}_{4}$ ), $150 \mathrm{ppm} \mathrm{K}$ (supplied by $\mathrm{K}, \mathrm{SO}_{4}$ ), and either $0,5,10,20,40,80,160,320$, or $640 \mathrm{ppm} \mathrm{N}$ (supplied by $\mathrm{NH}_{4} \mathrm{NO}_{3}$ ). The treatment excluding $\mathrm{NH}_{4} \mathrm{NO}_{3}$ served as the control. Fertilizer solutions were adjusted to $\mathrm{pH} 5.5$ to 6.0 with $2 \mathrm{M} \mathrm{NaOH}$ and applied weekly in late afternoon. Seedlings received 3 liters of solution per application.

The design was a randomized complete block, consisting of nine treatments ( $\mathrm{N}$ levels) and 22 blocks, with one replicate per block. Treatments were blocked to account for possible nonuniformity in irrigation spray distribution.

Data collection-Growth studies and foliar sampling. Height and stem diameter were recorded initially (15 May 1989) and every 35 days thereafter, with the last measurements taken after 175 days on 10 Nov. At 180 days, plants were severed above the uppermost roots, and root and shoot (stem with accompanying branches and foliage) weights were recorded following drying at $70 \mathrm{C}$ for 3 days.

Foliage samples were collected initially and every 60 days thereafter until 15 Nov. (180 days). A composite sampling tech- 
nique was used. Within each treatment, the 22 blocks were divided into four groups: blocks 1-6, 7-12, 13-18, and 19-22; grouping of blocks was based on spatial proximity. From each plant within a group, one $12-\mathrm{cm}$ shoot was removed from the distal portion of lateral branches in the upper third of the crown. Initially, it was not possible to remove $12-\mathrm{cm}$ shoots from this location due to limited growth. Therefore, shorter shoots were removed from adjacent branches and combined to give a total sample length of $12 \mathrm{~cm}$. Composite samples were formed for each group and placed on dry ice until completion of sampling. Samples were washed with dilute $(0.1 \mathrm{~N}) \mathrm{HCl}$, rinsed with deionized water, and stored at $-23 \mathrm{C}$ until freeze-dried, weighed, and ground to pass a 20-mesh (1.3-mm openings) screen. Processed samples were stored in desiccators pending nutrient and carbohydrate analysis.

Mineral nutrient analyses. Dried tissue samples were combusted at $475 \mathrm{C}$ for $5 \mathrm{~h}$. Ash was dissolved in $5.0 \mathrm{ml}$ concentrated $\mathrm{HCl}$ and diluted to $50 \mathrm{ml}$ with distilled, deionized water. An aliquot from this solution $(1.2 \mathrm{~N} \mathrm{HCl})$ was analyzed for $\mathrm{P}$, $\mathrm{K}, \mathrm{Ca}, \mathrm{Mg}, \mathrm{Mn}, \mathrm{B}, \mathrm{Fe}, \mathrm{Cu}$, and $\mathrm{Zn}$ with an inductively coupled argon plasma emission spectrometer (Jarrell-Ash ICAP-9000 plasma spectrometer; Jarrell-Ash, Waltham, Mass.). Concentrations of $\mathrm{Zn}$ and $\mathrm{Cu}$ were below detection limits, and $\mathrm{Fe}$ exhibited excessive variation. Therefore, these nutrients were excluded from further consideration. Total $\mathrm{N}$ was determined using the micro-Kjeldahl procedure after $\mathrm{H}_{2} \mathrm{SO}_{4}$ digestion of $0.2 \mathrm{~g}$ plant tissue. Analyses were conducted at the Soil Testing and Plant Analysis Lab., Dept. of Agronomy, Virginia Polytechnic Institute and State Univ., Blacksburg (Donohue and Gettier, 1988).

Carbohydrate analyses. Tissue samples $(50 \mathrm{mg})$ were extracted twice with petroleum ether and three times with hot $80 \%$ $(\mathrm{v} / \mathrm{v})$ ethanol, centrifuged, and the soluble supernatant collected. The remaining starch pellet, after gelatinization and digestion with amyloglucosidase (Hubbard et al., 1990a), was incubated with glucose assay mix (Hubbard et al., 1990a) at 25C for 30 min. Absorbance $(340 \mathrm{~nm})$ was measured, and glucose determined by comparison with a standard curve. The ethanolic extract was evaporated to dryness using a Buchler Evapo-Mix (Buchler Instruments, Fort Lee, N.J.), resolubilized in water, and subjected to enzymatic analyses (Hubbard et al., 1990b). Sucrose and hexose concentrations were determined by comparison to standard curves.

Data analyses. Regression models (Table 1) were fitted using Proc NLIN (SAS Institute, 1990); model selection was based on $r^{2}$ values. For asymptotic curves, the value of the independent variable ( $\mathrm{N}$ concentration) that elicits maximum response (asymptote) cannot be determined. Thus, the $\mathrm{N}$ concentration resulting in optimal (90\% maximum) response was calculated from regression equations.

Response of dependent variables over time is presented for applied $\mathrm{N}$ concentrations of 0,40 , and $640 \mathrm{ppm}$. These concentrations were chosen to illustrate the minimum, mid-range, and maximum response.

\section{Results}

Growth response to applied $N$. Height and stem diameter increased with time (Fig. 1 A and B); height growth was accelerated initially and slowed sooner in the season. After 105 days, height and diameter growth at $640 \mathrm{ppm} \mathrm{N}$ were $80 \%$ and $55 \%$ complete, respectively. Nitrogen concentrations $<20 \mathrm{ppm}$ had little effect on growth (Fig. 2 A and B, Table 1). After 175 days, height $(73 \mathrm{~cm})$ and diameter $(12.9 \mathrm{~mm})$ were maximized
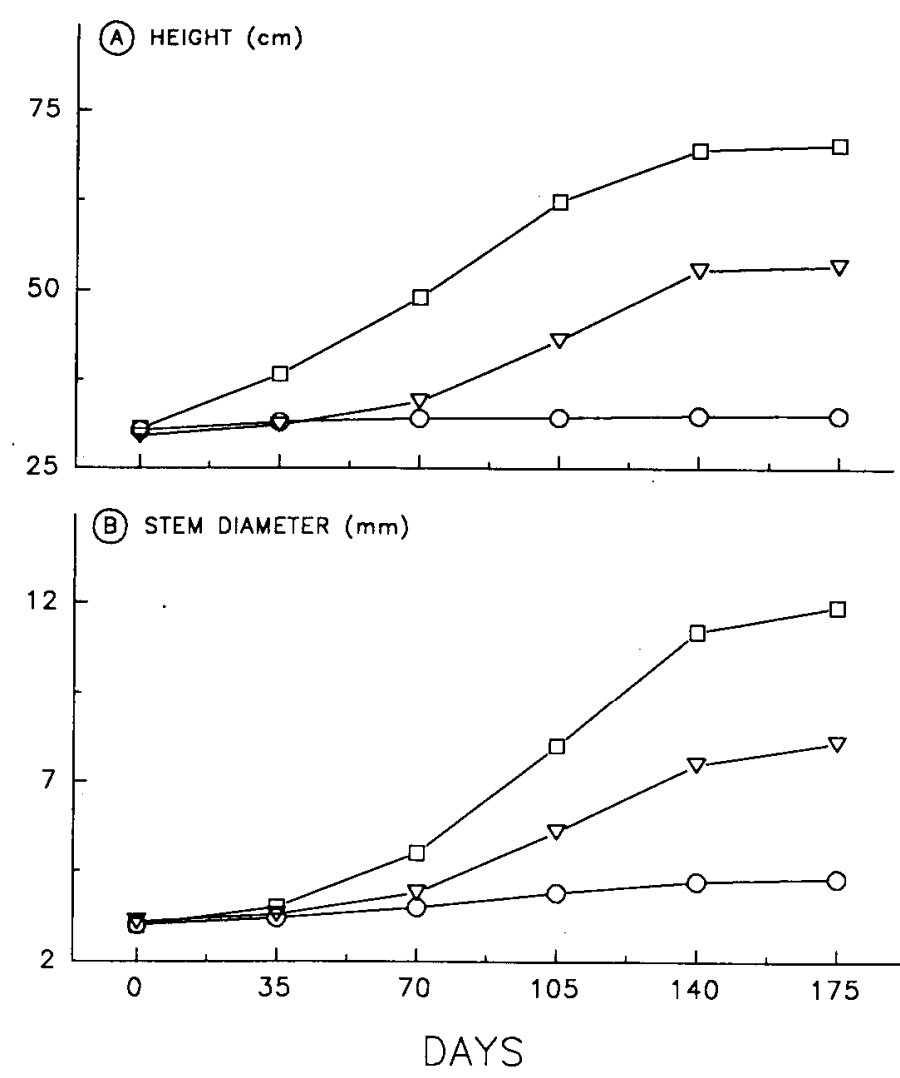

Fig. 1. Growth of containerized eastern redcedar at applied $\mathrm{N}$ concentrations of $0(O), 40(\nabla)$, and $640(\square)$ ppm. (A) height; (B) stem diameter. Each mean is based on 22 plants.
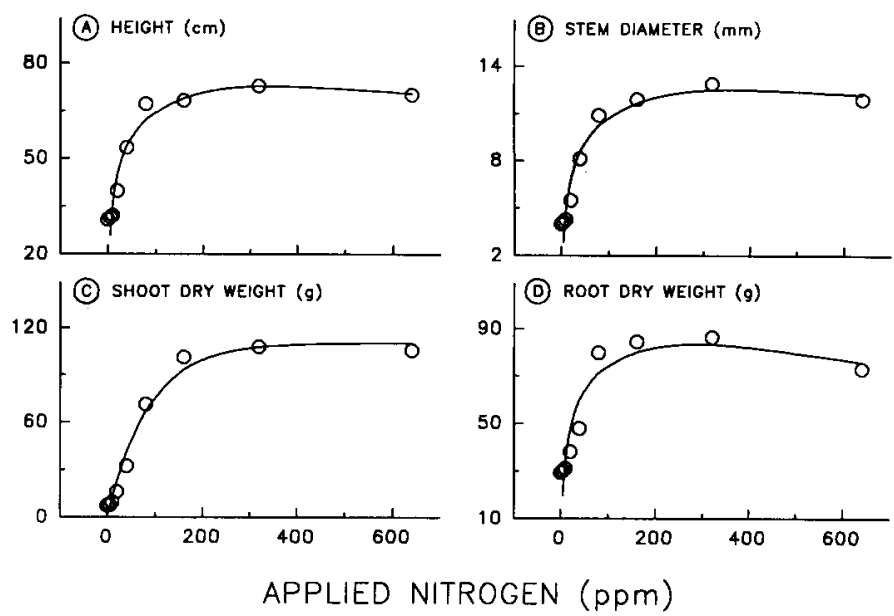

Fig. 2. Observed $(\mathrm{O})$ and predicted (-) growth after 175 (height, stem diameter) or 180 (shoot and root dry weights) days for containerized eastern redcedar fertilized weekly with various levels of N. (A) height; (B) stem diameter; (C) shoot dry weight; (D) root dry weight. Regression models and associated statistics are in Table 1. Each mean is based on 22 plants.

at $320 \mathrm{ppm} \mathrm{N}$, with optimal response at 115 and $155 \mathrm{ppm}$, respectively. Higher $\mathrm{N}$ levels $(640 \mathrm{ppm})$ resulted in slightly decreased height and stem diameter.

Shoot dry weight was asymptotic with applied N; response was optimal at $230 \mathrm{ppm} \mathrm{N}$ (Fig. 2C). Root dry weight, maximized $(83.4 \mathrm{~g}$ ) at $320 \mathrm{ppm} \mathrm{N}$, was optimal at $105 \mathrm{ppm}$ (Fig. 2D). Root : shoot ratio (data not presented) declined by $85 \%$ as $\mathrm{N}$ increased from 5 to $80 \mathrm{ppm}$ and remained stable at higher 
Table 1. Regression models and statistics associated with growth and foliar analysis data for containerized eastern redcedar at various $\mathrm{N}$ levels.

\begin{tabular}{|c|c|c|c|c|c|c|c|}
\hline \multirow[b]{2}{*}{ Variable } & \multirow[b]{2}{*}{ Fig. } & \multirow{2}{*}{$\begin{array}{l}\text { Model } \\
\text { type }\end{array}$} & \multicolumn{3}{|c|}{ Model terms } & \multirow{2}{*}{$\begin{array}{c}\text { Error } \\
\text { mean } \\
\text { squares }\end{array}$} & \multirow[b]{2}{*}{$R^{2}$} \\
\hline & & & B0 & $\mathrm{B} 1$ & $\mathrm{~B} 2$ & & \\
\hline Height & $2 \mathrm{~A}$ & 3 & 3.21 & -0.04 & 14.17 & 17.43 & 0.99 \\
\hline Stem diameter & $2 \mathrm{~B}$ & 3 & -1.74 & $-7.2 \times 10^{-3}$ & 2 & 0.80 & 0.99 \\
\hline Shoot dry weight & $2 \mathrm{C}$ & 1 & 111.01 & 0.01 & -0.40 & 48.81 & 0.99 \\
\hline Root dry weight & $2 \mathrm{D}$ & 3 & -13.12 & -0.07 & 20.50 & 86.63 & 0.99 \\
\hline Starch & $4 \mathrm{~A}$ & 3 & 0.0173 & $-7.1 \times 10^{-4}$ & 0.16 & $4.1 \times 10^{-3}$ & 0.99 \\
\hline Sucrose & $4 B$ & 4 & 8.15 & 0.28 & --- & 0.36 & 0.99 \\
\hline Hexose & $4 C$ & 1 & 0.70 & 0.03 & 1.28 & 0.05 & 0.99 \\
\hline$N$ & $4 \mathrm{D}$ & 4 & 4.90 & 0.08 & $\cdots$ & $8.6 \times 10^{-3}$ & 0.99 \\
\hline P & $4 \mathrm{E}$ & 1 & 0.15 & 0.03 & 0.09 & $1.4 \times 10^{-4}$ & 0.99 \\
\hline $\mathbf{K}$ & $4 \mathrm{~F}$ & 1 & 0.43 & 0.07 & 0.52 & $6.4 \times 10^{-3}$ & 0.99 \\
\hline $\mathrm{Ca}$ & $4 \mathrm{G}$ & 2 & 2.29 & 0.32 & --- & $5.7 \times 10^{-3}$ & 0.99 \\
\hline $\mathrm{Mg}$ & $4 \mathrm{H}$ & 2 & 0.34 & 0.12 & -- & $7.8 \times 10^{-5}$ & 0.99 \\
\hline $\mathrm{Mn}$ & $4 \mathrm{I}$ & 2 & $2.9 \times 10^{-3}$ & 0.01 & -- & $6.2 \times 10^{-7}$ & 0.99 \\
\hline B & $4 \mathrm{~J}$ & 1 & $9.3 \times 10^{-4}$ & 0.05 & $1.3 \times 10^{-3}$ & $6.0 \times 10^{-8}$ & 0.99 \\
\hline
\end{tabular}

zType 1: $\mathrm{Y}=\mathrm{B} 0[1-\exp (-\mathrm{B} 1 \times \mathrm{X})]+\mathrm{B} 2 ;$ Type $2: \mathrm{Y}=\left(\mathrm{B} 0 / \mathrm{X}^{0.5}\right)+\mathrm{B} 1 ;$ Type 3: $\mathrm{Y}=$ $\mathrm{B} 0+(\mathrm{B} 1 \times \mathrm{X})+[\mathrm{B} 2 \times \ln (\mathrm{X})] ;$ Type $4: \mathrm{Y}=\mathrm{B} 0\left(1-1 / \mathrm{X}^{\mathrm{B} 1}\right)$.

$\mathrm{N}$ levels. Root : shoot ratio at $5 \mathrm{ppm} \mathrm{N}$ (3.3) was 5.0 times that at $640 \mathrm{ppm}$.

Foliar carbohydrate concentrations over time. Starch concentration decreased over time (Fig. 3A). At 40 and $640 \mathrm{ppm}$ $\mathrm{N}$, concentrations after 60 days were one-fourth the level of nonfertilized controls. Concentration in controls remained high for 120 days, then declined rapidly to the level observed in other treatments $(0.80 \%)$.

Sucrose concentration was low through day 120 (Fig. 3B) and then increased sharply in fertilized plants. The maximum concentration (7.0\%), after 180 days for plants receiving 640 ppm N, was 3.5 times that for initial levels.

Hexose concentration at 0 and $40 \mathrm{ppm} \mathrm{N}$ remained fairly constant during the experiment (Fig. 3C). At $640 \mathrm{ppm}$, concentration doubled through 120 days, reaching a maximum of $4.1 \%$. The concentration subsequently declined and, at the final sampling date, was equal to that in plants of the $40-\mathrm{ppm} \mathrm{N}$ treatment $(2.0 \%)$.

Foliar nutrient concentrations over time. Foliar N, P, and $\mathrm{K}$ of treated plants increased over time (Fig. 3D-F); concentrations in controls remained fairly constant. Foliar $\mathrm{N}$ at $640 \mathrm{ppm}$ doubled through 60 days and increased gradually thereafter (Fig. 3D). Maximum $\mathrm{P}$ concentration $(0.27 \%)$, at 120 days for 640 ppm, was. 2.7 times that for initial values (Fig. 3E). Potassium concentration at 40 and $640 \mathrm{ppm}$ doubled during the first 60 days (Fig. 3F), reaching a maximum of $1.13 \%$ (640 ppm); concentration at $640 \mathrm{ppm}$ declined during the last 60 days.

Concentrations of $\mathrm{Ca}, \mathrm{Mg}$, and $\mathrm{Mn}$ in control plants increased over time and, after 180 days, were maximized at $1.23 \%, 0.30 \%$, and 0.01670 , respectively (Fig. 3G-I). Calcium concentration for $640 \mathrm{ppm}$ at day 180 was 2.6 times lower than initial values (Fig. 3G). Magnesium and Mn concentrations of treated plants remained constant (Fig. $3 \mathrm{H}$ and I).

Boron concentration of control plants remained constant (Fig. $3 \mathrm{~J})$. Concentration of treated plants increased sharply during the final 60 days, reaching a maximum of $0.0024 \%$ at $40 \mathrm{ppm} \mathrm{N}$.

Foliar carbohydrate concentrations at day 180. Foliar concentrations of starch, sucrose, and hexose increased sharply with applied $\mathrm{N}$ up to 20 to $40 \mathrm{ppm}$ (Fig. 4A-C). Maximum starch concentration $(0.73 \%)$, at 160 and $320 \mathrm{ppm} \mathrm{N}$, was 2.7 times that of the controls (Fig. 4A); at $640 \mathrm{ppm} \mathrm{N}$, starch concentra-
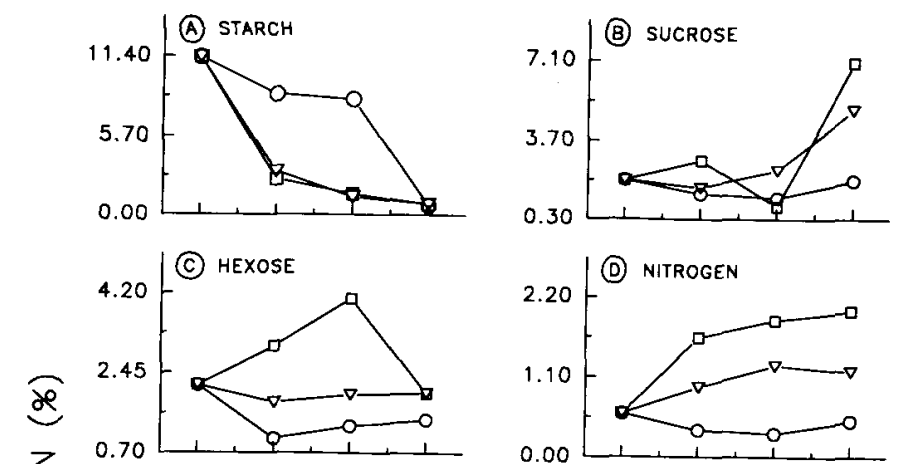

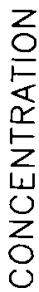
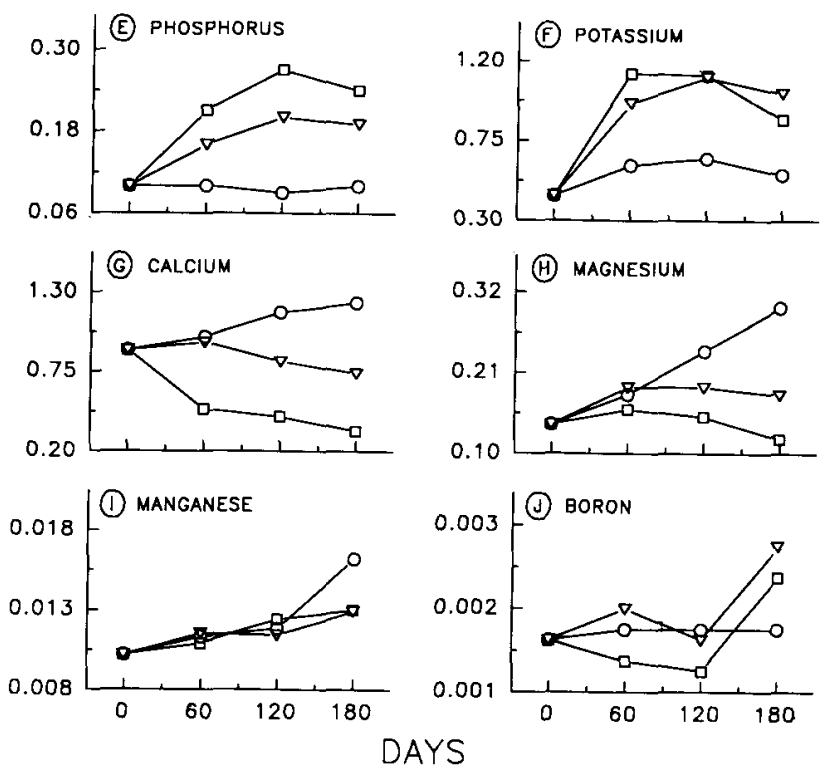

Fig. 3. Foliar carbohydrate and mineral nutrient concentrations of containerized eastern redcedar at applied $\mathrm{N}$ concentrations of $0(O)$, $40(\nabla)$, and 640 (口) ppm. (A) starch; (B) sucrose; (C) hexose; (D) $\mathrm{N}$; (E) P; (F) $\mathrm{K}$; (G) Ca; (H) $\mathrm{Mg}$; (I) $\mathrm{Mn}$; (J) B. Each mean is based on four composite replications.

tion declined by $20 \%$. Sucrose and hexose concentrations were asymptotic over applied $\mathrm{N} ; 90 \%$ maximum concentrations were obtained with 250 (Fig. 4B) and 40 ppm (Fig. 4C), respectively. 


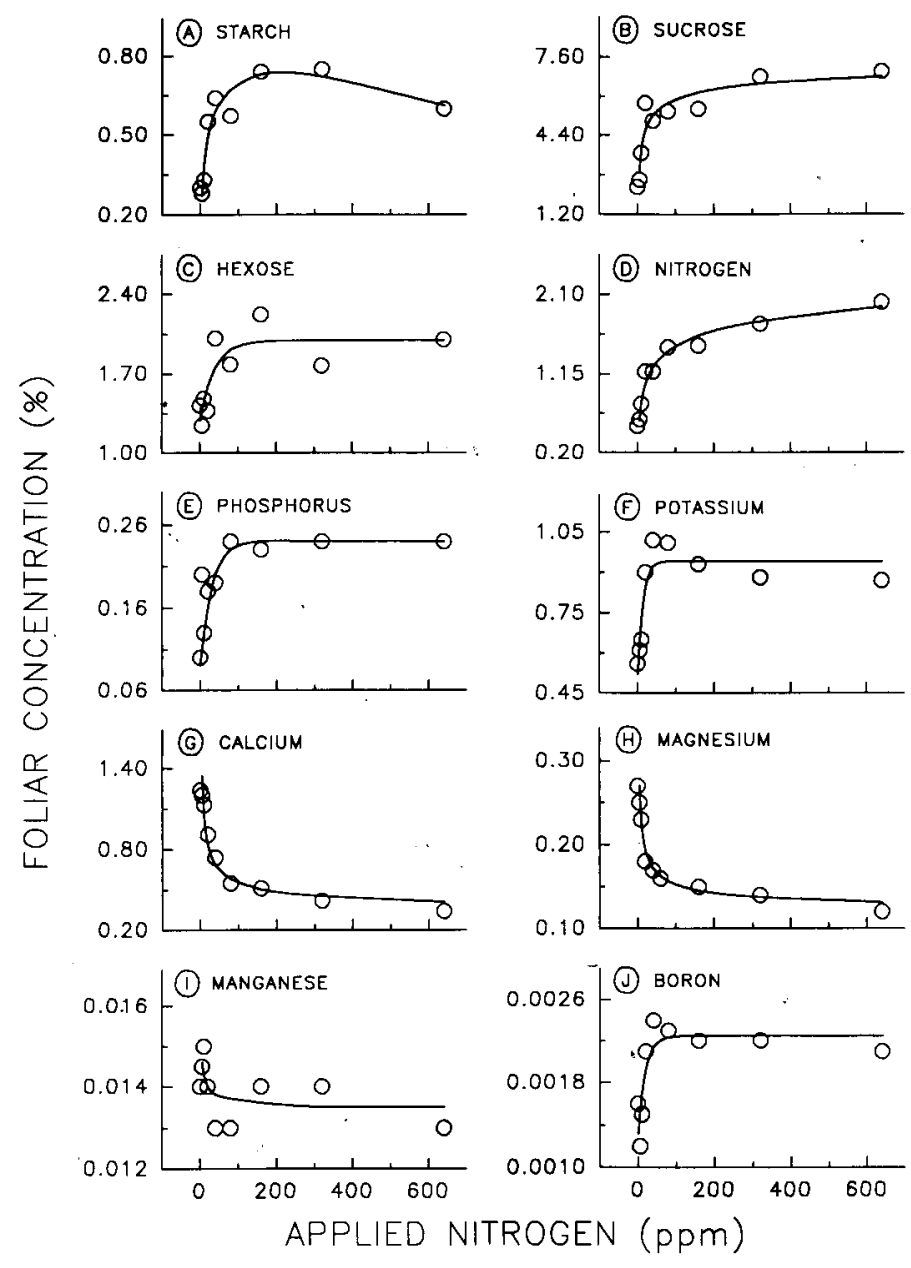

Fig. 4. Observed (O) and predicted (-) foliar carbohydrate and mineral nutrient concentrations after 180 days for containerized eastern redcedar fertilized weekly with various levels of N. (A) starch; (B) sucrose; (C) hexose; (D) N; (E) P; (F) K, (G) Ca; (H) Mg; (I) Mn; (J) B. Regression models and associated statistics are in Table 1. Each mean is based on four composite replications.

Foliar nutrient concentrations at day 180. Foliar N, P, K, and $\mathrm{B}$ increased sharply with applied $\mathrm{N}$ up to $40 \mathrm{ppm}$ (Fig. 4D$\mathrm{F}$ and $\mathrm{J}$ ) and were asymptotic at higher levels; 90\% maximum concentrations were obtained with $360,60,20$, and $25 \mathrm{ppm} \mathrm{N}$, respectively.

Calcium and $\mathrm{Mg}$ declined with applied $\mathrm{N}$ up to $40 \mathrm{ppm}$ (Fig. $4 \mathrm{G}$ and $\mathrm{H}$ ); maximum concentrations at the lowest $\mathrm{N}$ levels were 3 and 2 times, respectively, that at $640 \mathrm{ppm}$. Manganese concentrations were slightly higher in control plants than in plants that were fertilized (Fig. 41).

\section{Discussion}

Response to applied $\mathrm{N}$ can be expressed in terms of external supply or internal concentration. Fertilizer efficiency, defined as yield per unit fertilizer (Simpson, 1986), is one method of relating growth to supply. With respect to height and stem diameter growth, efficiency was maximized at $\mathrm{N}$ concentrations between 10 and $40 \mathrm{ppm}$ when these measurements increased an average of $0.62 \mathrm{~cm} / \mathrm{ppm}$ and $0.13 \mathrm{~mm} / \mathrm{ppm} \mathrm{N}$, respectively.

Height, stem diameter, and root dry weight were optimal at 115, 155, and 105 ppm N, respectively (Fig. 2), agreeing with recommendations of 100 to $150 \mathrm{ppm} \mathrm{N}$ for container-grown conifers (Landis et al., 1989; Morrison, 1974). Shoot dry weight was optimal at $230 \mathrm{ppm} \mathrm{N}$. As with other conifers (Fowells and Krauss, 1959; Stewart and Swan, 1970), root : shoot ratio declined as $\mathrm{N}$ concentration approached that necessary for optimal height and diameter growth.

Height growth was negligible until foliar $\mathrm{N}$ concentrations reached $1.2 \%$, where it sharply increased (Fig. 5). Similar increases in yield, accompanied by little change in foliar $\mathrm{N}$, have been noted in other species (Smith, 1962). The foliar N concentration resulting in $90 \%$ height yield (critical level) was $1.5 \%$.

Starch accumulation was maximum in spring, coinciding with the onset of higher temperatures and increased daylength. The rate of decline during the growing season depended on fertility status (Fig. 3A). When plants received adequate N, starch was mobilized rapidly to support high sink demands. When $\mathrm{N}$ fertility limited growth, starch use was slow and high levels were maintained throughout summer. Decreased concentration in control plants as winter approaches has been noted in other species (Ericsson, 1979; Venator, 1982), perhaps due to accumulation of reserves in roots and consumption via maintenance respiration (Adams et al., 1986).

Sucrose concentrations increased in the fall (Fig. 3B). Accumulation of soluble carbohydrates in other conifers during fall (Ericsson, 1979; Krueger and Trappe, 1967; Little, 1970) has been attributed to continued carbon fixation, accompanied by cessation of vegetative growth and decreased respiration (Krueger and Trappe, 1967). Accumulation might be associated with increased cold hardiness (Little, 1970), as demonstrated for raffinose, which fluctuates seasonally in Fraser fir [Abies fraseri (Pursh) Poir.] (Mitcham-Butler et al., 1987).

Although reduced $\mathrm{N}$ fertility reportedly increases carbohydrate accumulation (Mengle and Kirkby, 1982), accumulation was minimal in eastern redcedar when plants received $<20 \mathrm{ppm}$ N.

The relationship of foliar $\mathrm{N}$ to supplied $\mathrm{N}$ is generally asymptotic (van den Driessche, 1974), and optimal supply levels vary between species. Foliar $\mathrm{N}$ in Scots pine (Pinus sylvestris L.) was linearly related to supply at levels up to $400 \mathrm{ppm}$, whereas response for eastern white pine (Pinus strobus L.) was asymp-

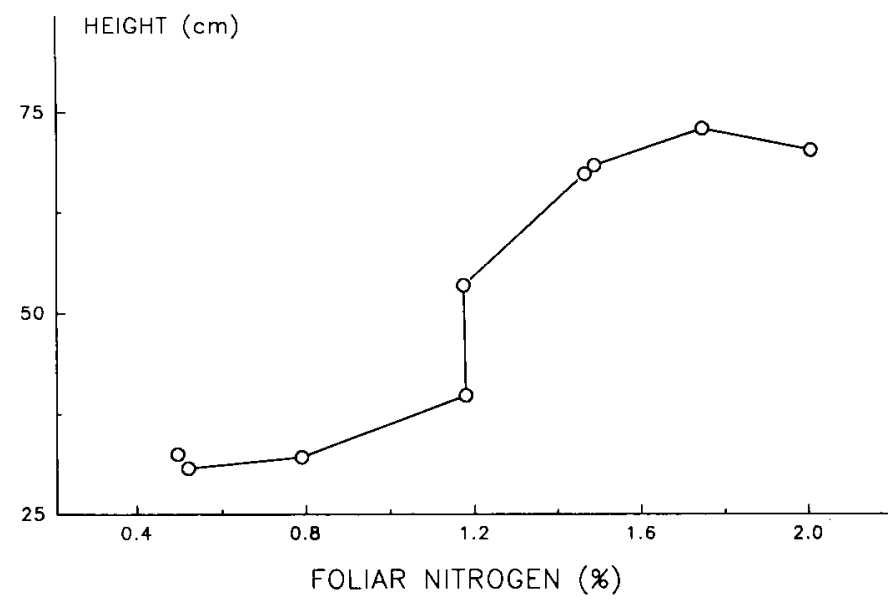

Fig. 5. Height growth of containerized eastern redcedar after 175 days in relation to foliar $\mathrm{N}$ concentrations. Each mean is based on four composite replications. 
totic at the same concentration (Mitchell, 1934). In eastern redcedar, foliar $\mathrm{N}$ increased sharply at applied $\mathrm{N}$ concentrations up to $80 \mathrm{ppm}$ (Fig. 4D) and was optimal at $360 \mathrm{ppm}$.

Increased $\mathrm{N}$ supply reportedly suppresses foliar $\mathrm{P}$ and $\mathrm{K}$ (Cain, 1959; Fowells and Krauss, 1959; Smith, 1962 Sparks and Baker, 1975). With eastern redcedar, there was no evidence of suppression since both nutrients increased with $\mathrm{N}$ supply up to $80 \mathrm{ppm}$ and remained constant at higher $\mathrm{N}$ levels.

Increased $\mathrm{N}$ supply was associated with reduced foliar $\mathrm{Ca}$ (Fig. 4G) and Mg (Fig. 4H). The decline in Ca concentration through $80 \mathrm{ppm} \mathrm{N}$ suggests that the nutrient was used structurally to support intensive growth. Reduced $\mathrm{Ca}$, noted in other species (Fowells and Krauss, 1959; Leyton, 1958; Sparks and Baker, 1975), results from competition with cations that are taken up more readily by roots (Mengle and Kirkby, 1982). Magnesium uptake might be similarly restricted, although foliar Mg increases with N supply in some species (Cain, 1959; Smith, 1962).

Concentrations of $\mathrm{Cu}$ and $\mathrm{Zn}$ in plants were below detection limits of the plasma spectrometer used for analysis. Absence of visual deficiency symptoms suggests that eastern redcedar requires extremely low concentrations of these micronutrients.

Summary. Nitrogen fertility strongly affected growth and nutritional status of containerized eastern redcedar. Height, stem diameter, and root dry weight were optimal at 105 to $155 \mathrm{ppm}$ applied $\mathrm{N}$, higher concentrations were required for optimal shoot dry weight. Foliar carbohydrate and mineral nutrient concentrations were asymptotic with applied N. Starch, sucrose, hexose, $\mathrm{N}, \mathrm{P}, \mathrm{K}$, and $\mathrm{B}$ exhibited a positive response, while $\mathrm{Ca}, \mathrm{Mg}$, and $\mathrm{Mn}$ declined with increasing $\mathrm{N}$ supply.

\section{Literature Cited}

Adams, M.B., H.L. Allen, and C.B. Davey. 1986. Accumulation of starch in roots and foliage of loblolly pine (Pinus taeda L.): Effects of season, site, and fertilization. Tree Physiol. 2:35-46.

Cain, J.C, 1959. Plant tissue analysis. Part II. Observations on antagonistic effects in leaf analysis. Mineral nutrition of trees: A symposium. Duke Univ. School For. Bul. 15. p. 63-70.

Donohue, S.J. and S.W. Gettier. 1988. Soil testing and plant analysis: Laboratory procedures. Virginia Coop. Ext. Serv. Publ. 452-881.

Ericsson. A. 1979. Effects of fertilization and irrigation on the seasonal changes of carbohydrate reserves in different age-classes of needles on 20-year-old Scots pine trees (Pinus sylvestris). Physiol. Plant. 45:270-280.

Fletcher, P.W. and J. Ochrymowych. 1955. Mineral nutrition and growth of eastern redcedar in Missouri. Missouri Agr. Expt. Sta. Res. Bul. 577.
Fowells, H.A. and R.W. Krauss. 1959. The inorganic nutrition of loblolly pine with special reference to nitrogen and phosphorus. Forest Sci. 5:95-112.

Hubbard, N.L.. D.M. Pharr, and S.C. Huber. 1990a. Role of sucrose biosynthesis in ripening bananas and its relationship to the respiratory climacteric. Plant Physiol. 94:201-208.

Hubbard, N.L., D.M. Pharr, and S.C. Huber. 1990b. Sucrose metabolism in ripening muskmelon fruit as affected by leaf area. J. Amer. Soc. Hort. Sci. 115:798-802.

Johnsen, T.N., Jr., and R.A. Alexander. 1974. Juniperus L. juniper, p. 460-469. In: C.S. Schopmeyer (technol. coordinator). Seeds of woody plants in the United States. U.S. Dept. Agr. Forest Serv., Agr. Hdbk. 450.

Krueger, K.W. and J.M. Trappe. 1967. Food reserves and seasonal growth of Douglas-fir seedlings. Forest Sci. 13:192-202.

Landis, T.D., R.W. Tinus, S.E. McDonald, and J.P. Barnett. 1989. The container tree nursery manual. vol. 4. Seedling nutrition and irrigation. U.S. Dept. Agr. Forest Serv., Agr. Hdbk. 674.

Leyton, L. 1958. The relationship between the growth and mineral nutrition of conifers, p. 323-346. In: K.V. Thimann (ed.). Physiology of forest trees. Ronald Press, New York.

Little, C.H.A. 1970. Seasonal changes in carbohydrate and moisture content in needles of balsam fir (Abies balsamea). Can. J. Bot. 48:2021-2028.

Mengle, K. and E.A. Kirkby. 1982. Principles of plant nutrition. Intl. Potash Inst., Bern, Switzerland.

Mitcham-Butler, E.J., L.E. Hinesley, and D.M. Pharr. 1987. Soluble carbohydrate concentration of Fraser fir foliage and its relationship to postharvest needle retention. J. Amer. Soc. Hort. Sci. 112:672676.

Mitchell, H.L. 1934. Pot culture tests of forest soil fertility. Black Rock Forest Bul. 5.

Morrison. I.K. 1974. Mineral nutrition of conifers with special reference to nutrient status interpretation: A review of literature. Can. Forest Serv., Ottawa. Publ. 1343.

SAS Institute. 1990. SAS/STAT user's guide. vol. 2. SAS Institute, Inc., Cary, N.C.

Simpson, K. 1986. Fertilizers and manures. Longman, New York.

Smith. P.F. 1962. Mineral analysis of plant tissue. Annu. Rev. Plant Physiol. 13:81-108.

Sparks, D. and D.H. Baker. 1975. Growth and nutrient response of pecan seedlings, Carya illinoensis Koch, to nitrogen levels in sand culture. J. Amer. Soc. Hort. Sci. 100:392-399.

Stewart, H. and D. Swan. 1970. Relationships between nutrient supply, growth, and nutrient concentrations in the foliage of black spruce and jack pine. Pulp Paper Res. Inst. Canada. Woodlands Paper 19.

van den Driessche, R. 1974. Prediction of mineral nutrient status of trees by foliar analysis. Bot. Rev. 40:347-394.

Venator, C.R. 1982. Seasonal changes in chemical components of loblolly pine seedlings. Proc. 7th North Amer. Forest Biol. Wkshp., Lexington, Ky. 7:314-320. 